\section{Contact lens-related microbial keratitis: how have epidemiology and genetics helped us with pathogenesis and prophylaxis}

F Stapleton ${ }^{1,2,3}$ and N Carnt ${ }^{1,2}$

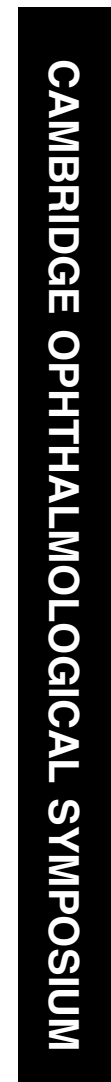

Keywords: corneal infection; contact lens; microbial keratitis

Microbial keratitis is a potentially blinding corneal infection, which occurs rarely in the normal eyes. ${ }^{1-3}$ Predisposing factors have included ocular surface disease, ocular trauma, contact lens wear, systemic diseases, and ocular surgery. ${ }^{2,4-7}$ In a working age population, the two major preventable predisposing factors are ocular trauma and contact lens wear, ${ }^{5,7}$ each accounting for $1 / 3$ of new cases presenting to a tertiary referral centre in Australia. ${ }^{7}$

Our understanding of prevention and prophylaxis of contact lens-related microbial keratitis has been informed by several recent well-designed prospective epidemiological studies describing incidence rates and risk factors, and recent evidence for causative organisms, pathophysiology, and the differences between individuals. This paper aims to summarise information relevant to limiting the morbidity associated with this condition.

Epidemiology of microbial keratitis with contemporary contact lenses

Tables 1-3 summarise the incidence estimates from a range of studies with hydrogel, silicone
${ }^{2}$ School of Optometry and Vision Science, University of New South Wales, Sydney, New South Wales, Australia

${ }^{3}$ Vision CRC, Sydney, New South Wales, Australia

Correspondence: F Stapleton, School of Optometry and Vision Science, University of New South Wales, Sydney, New South Wales 2052, Australia

Tel: + 61293854375 ;

Fax: + 61293136243 .

E-mail: F.Stapleton@

unsw.edu.au

Received: 10 October 2011 Accepted: 12 October 2011 Published online: 2

December 2011

This work was presented at the Cambridge Ophthalmological Symposium, September 2011. 
Table 1 Studies describing the unadjusted annualised incidence of presumed microbial keratitis and vision loss in hydrogel contact lens wear, stratified by selection of controls (adapted from Stapleton $e^{a l^{78}}$ )

\begin{tabular}{|c|c|c|c|c|c|c|}
\hline $\begin{array}{l}\text { First } \\
\text { author }\end{array}$ & $\begin{array}{l}\text { Total } \\
\text { cases }\end{array}$ & $\begin{array}{c}\text { Definition of } \\
\text { microbial keratitis }\end{array}$ & Study design & Location & $\begin{array}{c}\text { Incidence per } \\
10000 \\
(95 \% \mathrm{CI}) \\
\text { Daily wear }\end{array}$ & $\begin{array}{c}\text { Incidence per } \\
10000 \\
(95 \% \mathrm{CI}) . \\
\text { Extended wear }\end{array}$ \\
\hline
\end{tabular}

Denominator derived from random telephone survey of the community to identify penetrance of contact lens wearers.

\begin{tabular}{|c|c|c|c|c|c|c|}
\hline Stapleton ${ }^{11}$ & 285 & $\begin{array}{l}\text { Clinical diagnosis of microbial } \\
\text { keratitis with either a positive } \\
\text { corneal culture or infiltrate } \\
\text { with overlying epithelial defect, } \\
\text { with one or more of: lesion } \\
\text { in the central cornea; anterior } \\
\text { chamber response; and pain }\end{array}$ & $\begin{array}{l}\text { 12-month prospective } \\
\text { surveillance } \\
\text { of practicing } \\
\text { ophthalmologists } \\
\text { and optometrists }\end{array}$ & Australia & $\begin{array}{l}1.9(1.8-2.0) \\
\text { Vision loss } \\
0.4(0.4-0.4)\end{array}$ & $\begin{array}{l}19.5(14.6-29.5) \\
\text { Vision loss } \\
4.0(2.9-6.6)\end{array}$ \\
\hline Cheng $^{9}$ & 92 & $\begin{array}{l}\text { Clinical diagnosis of microbial } \\
\text { keratitis in cosmetic contact } \\
\text { lens wearers, excluding viral } \\
\text { keratitis. Self-limiting small } \\
\text { corneal lesions excluded }\end{array}$ & $\begin{array}{l}\text { 3-month prospective } \\
\text { surveillance of } \\
\text { all practicing } \\
\text { ophthalmologists }\end{array}$ & Netherlands & $3.5(2.7-4.5)$ & $20.0(10.3-35.0)$ \\
\hline Seal $^{74}$ & 27 & $\begin{array}{l}\text { Presumed non-viral microbial } \\
\text { keratitis }\end{array}$ & $\begin{array}{l}8 \text {-month prospective, } \\
\text { population surveillance } \\
\text { via } 8 \text { hospitals }\end{array}$ & $\begin{array}{l}\text { Western } \\
\text { Scotland }\end{array}$ & $2.7(1.6-3.7)$ & - \\
\hline Poggio $^{16}$ & 195 & $\begin{array}{l}\text { Corneal stromal infiltrate } \\
\text { with an overlying epithelial } \\
\text { abnormality (ulceration) } \\
\text { clinically diagnosed as } \\
\text { microbial keratitis, received } \\
\text { antibiotic treatment }\end{array}$ & $\begin{array}{l}\text { 4-month prospective } \\
\text { surveillance of } \\
\text { all practicing } \\
\text { ophthalmologists }\end{array}$ & $\begin{array}{l}\text { Five states } \\
\text { in northern } \\
\text { United States }\end{array}$ & $4.1(2.9-5.2)$ & $20.9(15.1-26.7)$ \\
\hline \multicolumn{7}{|c|}{ Denominator derived from fitting surveys. CL type and modality by matched controls } \\
\hline Morgan $^{75}$ & 38 & $\begin{array}{l}\text { Prospective identification } \\
\text { of corneal infiltrative events } \\
\text { associated with CL wear. } \\
\text { 'Severe' keratitis defined as } \\
\text { cases with clinical severity } \\
\text { score }>8 / 22 \text { National fitting } \\
\text { data applied to estimated } \\
\text { hospital catchment population }\end{array}$ & $\begin{array}{l}\text { 12-month prospective } \\
\text { study of patients } \\
\text { presenting to } \\
\text { hospital accident } \\
\text { and emergency clinic }\end{array}$ & $\begin{array}{l}\text { Royal } \\
\text { Eye Hospital, } \\
\text { Manchester, } \\
\text { UK }\end{array}$ & $6.9(6.3-7.5)$ & $96.4(37.5-245.2)$ \\
\hline $\mathrm{Lam}^{10}$ & 59 & $\begin{array}{l}\text { Clinical diagnosis, corneal } \\
\text { stromal infiltrate }>1 \mathrm{~mm}^{2} \\
\text { usually but not necessarily } \\
\text { with an overlying epithelial } \\
\text { defect, excluding inflammatory, } \\
\text { herpetic and adenoviral } \\
\text { keratitis. Retrospective fitting } \\
\text { survey data (1994) applied } \\
\text { to } 1998 \text { census data }\end{array}$ & $\begin{array}{l}\text { 17-month prospective } \\
\text { survey of two } \\
\text { hospitals and } \\
27 \text { private } \\
\text { ophthalmologists }\end{array}$ & Hong Kong & $3.1(2.1-4.0)$ & $9.3(4.9-13.7)$ \\
\hline \multicolumn{7}{|c|}{ Denominator derived from practitioner fitting surveys } \\
\hline Nilsson $^{76}$ & 26 & $\begin{array}{l}\text { CL induced keratitis, defined } \\
\text { as full epithelial defect with a } \\
\text { stromal infiltrate or full ulcer. }\end{array}$ & $\begin{array}{l}\text { 3-month prospective } \\
\text { national surveillance } \\
\text { of all ophthalmologists }\end{array}$ & Sweden & $\begin{array}{l}2.2(0.4-3.9) \\
\text { Vision loss } \\
0.5(0.3-0.8)\end{array}$ & $13.3(4.1-22.6)$ \\
\hline
\end{tabular}

Abbreviations: $\mathrm{CI}$, confidence interval; $\mathrm{CL}$, contact lens.

hydrogel, and daily disposable contact lenses, respectively. Incidence rates appear not to be appreciably different with contemporary contact lens materials and wear modalities. Two key findings are that the incidence rate for microbial keratitis with overnight use of silicone hydrogel lenses is no different to that of hydrogel contact lenses ( 1 per 500 wearers per year), and that daily disposable contact lenses were not associated with a lower risk for all microbial keratitis than daily wear frequent replacement contact lenses.

Independent risk factors for microbial keratitis show some variation between studies, possibly due to 
Table 2 Studies describing the annualised incidence of presumed microbial keratitis in silicone hydrogel contact lens wear, stratified by selection of controls (adapted from Stapleton $\mathrm{et}_{\mathrm{al}} \mathrm{P}^{78}$ )

\begin{tabular}{|c|c|c|c|c|c|}
\hline $\begin{array}{l}\text { Author } \\
\text { (total cases) }\end{array}$ & Definition & Study design & Location & $\begin{array}{c}\text { Incidence per } \\
10000(95 \% \text { CI). } \\
\text { Daily wear }\end{array}$ & $\begin{array}{c}\text { Incidence per } \\
10000(95 \% \mathrm{CI}) \\
\text { Extended wear }\end{array}$ \\
\hline \multicolumn{6}{|c|}{ Denominator derived from random telephone survey of the community to identify penetrance of contact lens wearers } \\
\hline Stapleton $^{11}$ & $\begin{array}{l}\text { Clinical diagnosis of microbial } \\
\text { keratitis with either a positive } \\
\text { corneal culture or infiltrate with } \\
\text { overlying epithelial defect, with } \\
\text { one or more of: lesion in the } \\
\text { central cornea; anterior chamber } \\
\text { response; pain }\end{array}$ & $\begin{array}{l}\text { 12-month prospective } \\
\text { surveillance } \\
\text { of practicing } \\
\text { ophthalmologists } \\
\text { and optometrists. }\end{array}$ & Australia & $\begin{array}{l}11.9(10.0-14.6) \\
44 \text { cases } \\
\text { Vision loss } \\
1.1(0.9-1.4)\end{array}$ & $\begin{array}{l}25.4(21.2-31.5) \\
92 \text { cases } \\
\text { Vision loss } \\
2.8(2.3-3.5)\end{array}$ \\
\hline \multicolumn{6}{|c|}{ Prospective cohort study, 6245 participants using a silicone hydrogel lens on an extended wear schedule, 5561 wearer years of experience } \\
\hline Schein 77 & $\begin{array}{l}\text { Presumed microbial keratitis } \\
\text { based on presenting signs } \\
\text { and symptoms and review } \\
\text { by endpoint adjudication } \\
\text { committee }\end{array}$ & $\begin{array}{l}\text { 12-month prospective } \\
\text { cohort postmarket } \\
\text { surveillance study }\end{array}$ & $\begin{array}{l}131 \text { clinical practices } \\
\text { widely distributed } \\
\text { across North America }\end{array}$ & $\mathrm{N} / \mathrm{A}$ & $\begin{array}{l}18.0(8.5-33.1) \\
10 \text { cases } \\
\text { Vision loss } \\
3.6(0.4-12.9)\end{array}$ \\
\hline \multicolumn{6}{|c|}{ Denominator derived from fitting surveys, $C L$ type and modality by matched controls } \\
\hline Morgan $^{75}$ & $\begin{array}{l}\text { Prospective identification } \\
\text { of corneal infiltrative events } \\
\text { associated with CL wear. } \\
\text { 'Severe' keratitis defined } \\
\text { as cases with clinical } \\
\text { severity score }>8 / 22 \text {. } \\
\text { National fitting data applied } \\
\text { to estimated hospital } \\
\text { catchment population }\end{array}$ & $\begin{array}{l}\text { 12-month prospective } \\
\text { study of patients } \\
\text { presenting to } \\
\text { hospital accident } \\
\text { and emergency } \\
\text { clinic }\end{array}$ & $\begin{array}{l}\text { Royal Eye Hospital, } \\
\text { Manchester, UK }\end{array}$ & $\begin{array}{l}0.0(0.0-210.1) \\
0 \text { cases }\end{array}$ & $\begin{array}{l}19.8(6.7-58.0) \\
3 \text { cases }\end{array}$ \\
\hline
\end{tabular}

Abbreviations: $\mathrm{CI}$, confidence interval; $\mathrm{CL}$, contact lens.

Table 3 Studies describing the annualised incidence of presumed microbial keratitis in daily disposable contact lens wear

\begin{tabular}{lcc}
\hline Study & $\begin{array}{c}\text { Number } \\
\text { of cases }\end{array}$ & $\begin{array}{r}\text { Incidence of presumed microbial } \\
\text { keratitis per 10000 (95\% CI). }\end{array}$ \\
\hline Stapleton $e a^{11}$ & 12 & $1.9(1.8-2.0)$ \\
Morgan et $^{75}$ & 8 & $4.9(2.5-9.6)$ \\
\hline
\end{tabular}

Abbreviation: CI, confidence interval.

differences in study design, differences in wear practises, and power to detect differences; however, modifiable risk factors that have been consistently reported include extended wear, ${ }^{2,8}$ a longer duration of extended wear; ${ }^{8-10}$ occasional overnight lens use, ${ }^{11}$ poor hygiene, ${ }^{8,10}$ including omission of or infrequent lens disinfection, ${ }^{2,12}$ omitted or infrequent case cleaning, ${ }^{11,13}$ and omission of handwashing before handling lenses ${ }^{14}$ and smoking. ${ }^{10,11,15}$ Non-modifiable risk factors reported include younger age, males, and socioeconomic class. ${ }^{2,14-16}$ Systemic risk factors include self-reported poor general health, ${ }^{17}$ diabetes ${ }^{8}$ and thyroid disease ${ }^{17}$ Most recently, an increased exposure (number of days of wear per week) in daily wear, hypermetropia, obtaining lenses via the
Internet or mail order, and the early period of lens wear have been identified as additional risk factors with contemporary lens types. ${ }^{11,14}$ Despite a higher unadjusted incidence rate for daily use of silicone hydrogel contact lenses compared with hydrogel contact lens use (Table 1), multivariable analyses have not identified lens material as an independent risk factor. ${ }^{11,14}$ Within such multivariable models, the risk factors identified typically accounts for $70-80 \%$ of the total risk. It is conceivable that other behaviour traits, not evaluated in these studies, including risk taking propensity ${ }^{18}$ and individual differences in susceptibility also contribute to this unexplained risk of disease.

\section{Disease severity}

Given the limited impact of new lens modalities in reducing the overall risk of contact disease, an alternative approach may be to examine disease severity and specific risk factors, which may predispose to a more severe phenotype. Disease severity is frequently reported as the rate of vision loss and 10-14\% of cases lose two lines of best-corrected spectacle acuity (Tables 1 and 2). Vision loss is strongly associated with keratitis caused by an 
environmental organism (Gram-negative bacteria, Nocardia sp, fungi or Acanthamoeba), rather than with other Gram-positive bacteria or a culture-negative outcome $(11.4 \times, 95 \%$ CI 4.2-30.9) and with remoteness to healthcare $\left(5.1 \times, 95 \%\right.$ CI 1.6-16.6) ${ }^{19}$ Disease severity may also be measured by cost and duration of disease. Both of these outcome measures are associated with the corneal culture result and with a delay in receiving appropriate treatment. ${ }^{19}$

While the risk of infection associated with daily disposable contact lenses is of a similar magnitude to that of other daily use lenses, the low rate of severe/moderate keratitis in daily disposable contact lenses (0.5 (CI 0.5-0.6) per 10000 wearers per year) compared with frequent replacement daily wear contact lenses (1.1 (CI 1.1-1.2) per 10000 wearers per year), and low risk of vision loss with this modality is of note. ${ }^{11,14}$ This is perhaps consistent with these lenses being disposed of after each wear rather than being exposed to risk factors associated with hygiene procedures. A preliminary study has described a greater proportion of culture-negative lesions in daily disposable wearers compared with other daily wear contact lens users. ${ }^{20}$ This low rate of severe disease when daily disposable lenses are worn on a strict daily disposable wear basis would suggest an advantage in reduced morbidity.

An analysis of independent risk factors for moderate and severe microbial keratitis among daily wear contact lens users has specifically indicated the importance of poor storage case hygiene and infrequent case replacement. ${ }^{21}$ When assessing the contribution of risk factors to disease load, attention to storage case cleaning and replacement could reduce the disease load by over $60 \% .{ }^{21}$ The significance of storage case hygiene practise in limiting severe disease would suggest the importance of microbial contamination of the storage case in microbial keratitis. Despite storage case contamination remaining common among asymptomatic wearers, ${ }^{22}$ there is evidence that the causative organism can be recovered from the storage case in microbial keratitis ${ }^{23-26}$ A recent study examining non-culturable organisms from the storage case has demonstrated a link between the number of bacterial species recovered and increased severity of keratitis. ${ }^{27}$ Based on this evidence, elimination of the storage case via daily disposable contact lens use or elimination of contamination through antimicrobial technologies, easily cleaned case designs, frequent case replacement or simplified case hygiene practise would be effective approaches to limit disease severity.

\section{Causative organisms}

The spectrum of causative organisms in all microbial keratitis varies by climate and predisposing factor.
In general, Gram-positive bacteria are more frequently recovered in temperate climate regions, ${ }^{5,7,28}$ and Gramnegative bacteria and fungi in tropical or sub-tropical climates. ${ }^{6,29-31}$ Fungi account for $5-40 \%$ of culture proven infections.

In non-contact lens-related disease, Gram-positive bacteria predominate, specifically $S$. aureus, coagulasenegative staphylococci, Strep. pneumoniae and viridians. ${ }^{5,7,28}$ In contrast, Pseudomonas aeruginosa is the most commonly recovered causative organism in contact lens-related disease, followed by Gram-positive bacteria, fungi and Acanthamoeba. ${ }^{32-36}$ Severe microbial keratitis with vision loss in contact lens wearers is more likely to be caused by an environmental pathogen, and to occur in tropical regions in association with high daytime temperatures. ${ }^{36}$ There is a further strong association between Acanthamoeba and contact lens-related disease, with up to $95 \%$ of Acanthamoeba keratitis cases attributed to contact lens wear. ${ }^{37}$

\section{Why P. aeruginosa?}

The strong association between $P$. aeruginosa and contact lens-related infection is intriguing. Although P. aeruginosa can elaborate a wide range of cell associated and extracellular virulence factors, which can initiate and potentiate the infection process and activate the host defence mechanisms (see Willcox ${ }^{38}$ for a review), the link with contact lens wear has not been fully elucidated. The lens, storage case, and ocular environment may offer a suitable survival niche for this environmental organism. $P$. aeruginosa can adhere to and colonise lens materials during wear and survive in contact lens storage cases (see Szczotka-Flynn et $a^{39}$ for a review), partly through its ability to grow as a resistant biofilm on lenses and cases, ${ }^{40}$ and partly due to innate ${ }^{41}$ or acquired resistance to contact lens disinfectants. ${ }^{42}$

The initiation of microbial keratitis probably requires a combination of unique bacterial virulence characteristics plus the physiological impact of contact lens wear on the cornea. Physiological changes as a result of contact lens wear, which are likely to affect resistance to infection, include inhibition of normal corneal epithelial cell shedding ${ }^{43}$ corneal epithelial thinning ${ }^{43}$ increased binding of bacteria to corneal epithelial cells ${ }^{43}$ possibly through exposure of specific bacterial adhesins on basolateral cell membranes, ${ }^{44}$ increased internalisation of bacteria through expression of membrane lipid rafts on corneal epithelial cells, ${ }^{45}$ reduced tear exchange, ${ }^{46}$ and disruption to the normal lid/cornea/tear resurfacing mechanism.

During lens wear, the relatively static post-contact lens environment may protect organisms from host defences and may prolong retention time of organisms at the 
ocular surface, allowing organisms to replicate. This environment may preferentially select for certain virulence characteristics. Evidence for this includes the change in genotype of organisms associated with contact lens-related infections. P. aeruginosa strains are differentiated by the presence of particular Type III secretion system genes to either exoS or exoU, encoding for exoenzymes $S$ and $U$, respectively. The exoenzymes are injected into the host cell and initially locate to the plasma cell membrane. The exoS gene is associated with an invasive phenotype, where strains possessing this gene invade epithelial cells, replicate intracellularly and produce cell death through disruption of the host cell actin cytoskeleton. ${ }^{47}$ Exoenzyme $U$ is a potent cytotoxin that damages the host cell membrane, and causes overwhelming inflammation and host tissue damage through intracellular phospholipase $\mathrm{A}_{2}$ activity. ${ }^{48}$ ExoUproducing strains replicate extracellularly. The majority of non-ocular clinical isolates (70-80\%) contain the exoS gene, ${ }^{49}$ which is consistent with the findings in noncontact lens-related microbial keratitis. In contact lensrelated disease, however, there is a greater representation of strains containing the exoU gene. ${ }^{50}$ (Figure 1) The genotypic selection of exoU isolates in contact lensrelated infections perhaps suggests that cytotoxicity is a more important and specific virulence factor in contact lens-related keratitis than in other P. aeruginosa infections.

Severe disease caused by $P$. aeruginosa results from the specific virulence factors of the organism and an extreme host inflammatory response initiated via a host-bacteria interaction between host pattern-recognition receptors (eg, Toll-like receptors) and the respective pathogenassociated molecular pattern. ${ }^{51}$ Strategies directed towards microbial virulence characteristics ${ }^{52}$ may be more successful in preventing or limiting disease severity rather than attempting to modulate the host response. Biofilm prevention or disruption, or inhibition of $P$. aeruginosa quorum sensing may limit disease severity.

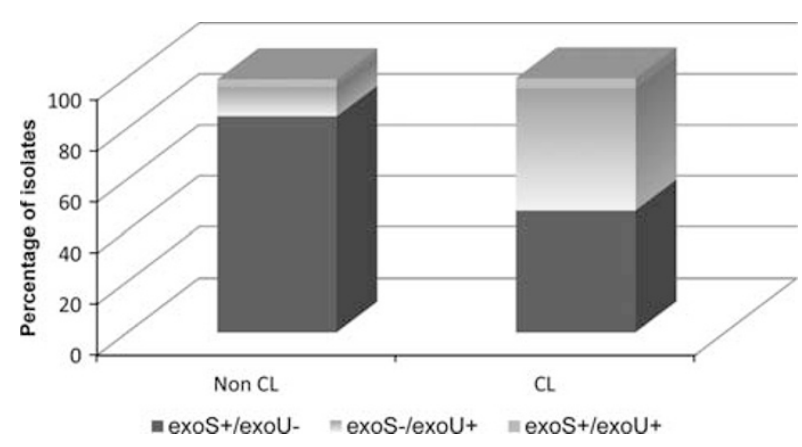

Figure 1 Distribution of type III secretion toxin genes exoU and exoS for $P$. aeruginosa strains from both non-contact lens and contact lens-related keratitis (after Choy et $a l^{50}$ ).

\section{Recent trends}

Certain contact lens care solutions were recently associated with outbreaks of Fusarium and Acanthamoeba keratitis, namely ReNu MoistureLoc (Bausch \& Lomb, Rochester, NY, USA) and Complete MoisturePlus (Abbott Medical Optics, Santa Ana, CA, USA), respectively. The Fusarium outbreak was initially detected via case series in Singapore ${ }^{53}$ and in the United States, ${ }^{54}$ and was subsequently described in two case control analyses. ${ }^{55,56}$ Independent risk factors are reported in Table 4 and both the studies confirmed the excess risk associated with $\mathrm{ReNu}$ MoistureLoc. The solution was recalled worldwide by May 2006. Laboratory studies demonstrated reduced fungicidal activity with this solution under conditions of prolonged increased temperatures, ${ }^{57}$ evaporation, ${ }^{58,59}$ and reuse.$^{58} \mathrm{~A}$ recent retrospective multicentre case series (2001-2007), reported on 695 cases of fungal keratitis including 283 contact lens wearers. ${ }^{60}$ Although the rate of Fusarium keratitis among contact lens wearers had reduced to the pre-outbreak levels, the rates of non-Fusarium fungal keratitis remained elevated. ${ }^{60}$

A year after the Fusarium outbreak, there was a similar pattern of increased reporting of contact lens-related keratitis in daily wear soft contact lens use due to Acanthamoeba. ${ }^{61-63}$ Independent risk factors were established in two case control studies (Table 5) and both

Table 4 Fusarium keratitis: risk factors

\begin{tabular}{|c|c|c|}
\hline Risk factor & $\begin{array}{l}\text { Singapore }^{56} \\
\text { Multivariate } \\
\text { analysis } \\
\text { (61 cases, } \\
345 \text { controls) }\end{array}$ & $\begin{array}{c}\text { US:CDC } \\
\text { Multivariate } \\
\text { analysis } \\
\text { (22 cases, } \\
32 \text { controls) }\end{array}$ \\
\hline \multicolumn{3}{|l|}{ Contact lens solution } \\
\hline Brands other than $\mathrm{ReNu}$ & 1.0 Referent & 1.0 Referent \\
\hline ReNu MoistureLoc only & $99.3(18.4-535.4)$ & $22.3(3.1-\infty)$ \\
\hline ReNu MultiPlus & $21.5(4.0-115.5)$ & NS \\
\hline $\begin{array}{l}\text { Contact lens replaced on } \\
\text { schedule }\end{array}$ & & $\begin{array}{l}\text { Not } \\
\text { examined }\end{array}$ \\
\hline Yes & 1.0 Referent & \\
\hline No & $4.8(1.7-13.8)$ & \\
\hline Reuse solution & NS & $-^{\mathrm{b}}$ \\
\hline Did not 'rub' lenses & Not examined & $\mathrm{NS}^{\mathrm{b}}$ \\
\hline Hand washing & Not examined & NS \\
\hline Case replacement & Not examined & NS \\
\hline Extended wear & NS & NS \\
\hline Swim in lenses & $N S^{b}$ & NS \\
\hline $\begin{array}{l}\text { Demographics: } \\
\text { age, gender, } \\
\text { income, ethnicity }\end{array}$ & $\begin{array}{l}\text { Age: NS, male }(3.3 \times) \text {, } \\
\text { high income }(3.8 \times) \text {, } \\
\text { Malaysian }(3.8 \times)\end{array}$ & NS \\
\hline
\end{tabular}

Abbreviations: CI, confidence interval; NS, not significant.

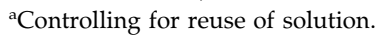

bSignificant in univariate analysis. 
Table 5 Acanthamoeba keratitis: risk factors

\begin{tabular}{|c|c|c|}
\hline Risk factor & $\begin{array}{c}\text { Chicago }^{64} \\
\text { Multivariable } \\
\text { analysis } \\
\text { (30 cases, } \\
39 \text { controls) }\end{array}$ & $\begin{array}{c}\text { USA }^{65} \\
\text { Multivariable } \\
\text { analysis } \\
\text { (72 cases, } \\
140 \text { controls) }\end{array}$ \\
\hline \multicolumn{3}{|l|}{ Contact lens solution } \\
\hline $\begin{array}{l}\text { Brands other than } \\
\text { Complete MoisturePlus }\end{array}$ & 1.0 Referent & 1.0 Referent \\
\hline Complete MoisturePlus & $18.50(2.11-162.63)$ & $16.9(4.8-59.5)$ \\
\hline \multicolumn{3}{|l|}{ Reuse of solution/topping off } \\
\hline Reuse $0-5 \times$ per month & 1.0 Referent & $\begin{array}{c}1.0 \text { Referent } \\
\text { (no topping off) }\end{array}$ \\
\hline Reuse $<5 \times$ per month & $3.17(0.82-12.33)^{\mathrm{a}}$ & $2.8(1.2-6.8)$ \\
\hline Rub to clean lenses & & NS \\
\hline Rub $<10 \times$ per month & 1.0 Referent & \\
\hline Rub $\leq 10 \times$ per month) & $9.05(0.82-100.19)^{\mathrm{a}}$ & \\
\hline Wear duration & Not examined & \\
\hline $\begin{array}{l}\text { Lenses worn } \\
\text { for }<5 \text { years }\end{array}$ & & 1.0 Referent \\
\hline $\begin{array}{l}\text { Lenses worn } \\
\text { for } \leq 5 \text { years }\end{array}$ & & $2.8(1.0-7.6)$ \\
\hline $\begin{array}{l}\text { Shower wearing lenses } \\
(<5 \times \text { per month })\end{array}$ & NS & Not examined \\
\hline $\begin{array}{l}\text { Lens replaced } \\
\text { (quarterly }+ \text { ) }\end{array}$ & NS & Not examined \\
\hline $\begin{array}{l}\text { Age of case at } \\
\text { replacement }(<3 \text { month })\end{array}$ & NS & Not examined \\
\hline Extended wear & NS & Not examined \\
\hline Lens material type & NS & NS \\
\hline
\end{tabular}

Abbreviation: NS, not significant.

${ }^{a}$ Conditional multivariable analysis, reporting factors significant at the $P<0.1$ level.

confirmed the excess risk associated with Complete MoisturePlus (Abbott Medical Optics, Santa Ana, CA) ${ }^{64,65}$ Unlike the previous outbreak, however, $<60 \%$ of cases used this product. A worldwide recall of the product was initiated in May 2007, however, since that time the disease has persisted, ${ }^{66}$ suggesting the contribution of additional unidentified risk factors.

In terms of limiting disease morbidity, there is limited contribution of hygiene and compliance risk factors other than reuse or topping off of solutions. Ongoing surveillance facilitates early detection, and there has been no licensing requirement for contact lens solutions to demonstrate efficacy against Acanthamoeba, consequently this is now currently under consideration by the FDA.

\section{Genetic factors in disease susceptibility and severity}

Genetic mutations in the innate immune system may be involved in individual susceptibility to microbial keratitis. Both susceptibility to and severity of inflammatory diseases have been linked to mutations of single bases (single-nucleotide polymorphisms, SNPs) and combinations of these bases (haplotypes) of cytokine and cytokine receptor genes. ${ }^{67}$ In a mouse model of corneal infection, Th2-responsive animals show a less severe microbial keratitis response than Th1 designated animals ${ }^{68}$ In contact lens wearers with bacterial keratitis, there is a relationship between haplotypes of interleukin (IL-)10 and the severity of and susceptibility to keratitis. ${ }^{69}$ The genotype of IL-6 (rs1800795) has been associated with severity of contact lens-related microbial keratitis, suggesting that IL-6 modulates disease severity. ${ }^{70}$

Contact lens wearers carrying one copy of the SNP were $3.1 \times(95 \%$ CI 1.1-8.3, $P=0.03)$ more likely to experience moderate/severe keratitis and those with two copies, were $6.4 \times(95 \%$ CI 1.4-28.4, $P=0.02)$ more at risk compared with those without the mutation..$^{70}$ The biological relevance and functionality of this SNP has been demonstrated, with reduced IL-6 production in juvenile chronic arthritis sufferers with the SNP. ${ }^{71}$ Similarly, in mouse models of $P$. aeruginos $a^{72}$ and S. aureus $^{73}$ keratitis, IL-6 is protective.

Individual immune profiles therefore can modulate the susceptibility and severity of corneal infections in contact lens wearers and may assist in predicting those at risk, particularly those wearers at risk of more severe disease.

\section{Conclusions}

Somewhat disappointingly, contemporary contact lenses appear to have not reduced the overall incidence of microbial keratitis. Risk factor analysis indicates that disease load is reduced by $60-70 \%$ by avoidance of overnight lens use and attention to lens hygiene factors. More severe disease is associated with an environmental causative organism and a delay in presentation for treatment. More significantly, a reduction in morbidity may be possible through recognition of appropriate risk factors, such as hygiene, specifically attention to storage case hygiene as both case cleaning and replacement reduces the risk of severe disease in daily contact lens use. Daily disposable lenses are associated with less severe disease. In two recent outbreaks of contact lensrelated infections due to unusual organisms, the antimicrobial efficacy of specific contact lens solutions has been a causal factor. As the recall of these products, the rate of Acanthamoeba keratitis has remained above baseline levels, indicating the impact of as yet unidentified risk factors. Individual differences in susceptibility may be partly explained by differences in SNPs in certain cytokine genes, particularly those with a protective role in corneal infection. 


\section{Conflict of interest}

The authors declare no conflict of interest. The Vision $\mathrm{CRC}$ and Brien Holden Vision Institute receive a royalty on the sales of certain contact lenses.

\section{References}

1 Musch DC, Sugar A, Meyer RF. Demographic and predisposing factors in corneal ulceration. Arch Ophthalmol 1983; 101: 1545-1548.

2 Dart JKG, Stapleton F, Minassian D. Contact lenses and other risk factors in microbial keratitis. Lancet 1991; 338: 650-654.

3 Miedziak AI, Miller MR, Rapuano CJ, Laibson PR, Cohen EJ. Risk factors in microbial keratitis leading to penetrating keratoplasty. Ophthalmology 1999; 106: 1166-1170.

4 Wong T, Ormonde S, Gamble G, McGhee CNJ. Severe infective keratitis leading to hospital admission in New Zealand. Br J Ophthalmol 2003; 87: 1103-1108.

5 Bourcier T, Thomas F, Borderie V, Chaumeil C, Laroche L. Bacterial keratitis: predisposing factors, clinical and microbiological review of 300 cases. Br J Ophthalmol 2003; 87: 834-839.

6 Fong CF, Tseng CH, Hu FR, Wang IJ, Chen WL, Hou YC. Clinical characteristics of microbial keratitis in a university hospital in Taiwan. Am J Ophthalmol 2004; 137: 329-336.

7 Keay L, Edwards K, Naduvilath T, Taylor HR, Snibson GR, Forde $\mathrm{K}$ et al. Microbial keratitis: predisposing factors and morbidity. Ophthalmology 2006; 113: 109-116.

8 Schein OD, Glynn RJ, Poggio EC, Seddon JM, Kenyon KR. The relative risk of ulcerative keratitis among users of dailywear and extended-wear soft contact lenses. $N$ Engl J Med 1989; 321: 773-778.

9 Cheng K, Leung D, Hoekman H, Beekhuis WH, Mulder PG, Geerards AJ et al. Incidence of contact-lens-associated microbial keratitis and its related morbidity. Lancet 1999; 354: 181-184.

10 Lam DSC, Houang E, Fan DSP, Lyon D, Seal D, Wong E. Incidence and risk factors for microbial keratitis in Hong Kong: comparison with Europe and North America. Eye 2002; 16: 608-618.

11 Stapleton F, Keay L, Edwards K, Naduvilath T, Dart JKG, Brian G et al. The incidence of contact lens related microbial keratitis. Ophthalmology 2008; 115: 1655-1662.

12 Stapleton F, Dart JKG, Minassian D. Risk factors in contact lens related suppurative keratitis. CLAO J 1993; 19: 204-210.

13 Radford CF, Minassian DC, Dart JKG. Disposable contact lens use as a risk factor for microbial keratitis. $\mathrm{Br} J$ Ophthalmol 1998; 82: 1272-1275.

14 Dart JKG, Radford CF, Minassian D, Verma S, Stapleton F. Risk factors for microbial keratitis with contemporary contact lenses: a case-control study. Ophthalmology 2008; 115: 1647-1654.e3.

15 Morgan PB, Efron N, Brennan NA, Hill EA, Raynor MK, Tullo AB. Risk factors for the development of corneal infiltrative events associated with contact lens wear. Invest Ophthalmol Vis Sci 2005; 46: 3136-3143.

16 Poggio EC, Glynn RJ, Schein OD, Seddon JM, Shannon MJ, Scardino VA et al. The incidence of ulcerative keratitis among users of daily-wear and extended-wear soft contact lenses. N Engl J Med 1989; 321: 779-783.
17 Keay L, Edwards K, Stapleton F. Signs, symptoms and co-morbidities in contact lens related microbial keratitis Optom Vis Sci 2009; 86: 803-809.

18 Carnt N, Keay L, Willcox M, Evans V, Stapleton F. Higher risk-taking propensity of contact lens wearers is associated with less compliance. Contact Lens Ant Eye 2010 doi:10.1016/j.clae.2010.10.004.

19 Keay L, Edwards K, Naduvilath T, Forde K, Stapleton F. Factors affecting the morbidity of contact lens related microbial keratitis: a population study. Invest Ophthalmol Visual Sci 2006; 47: 4302-4308.

20 Stapleton F, Naduvilath T, Keay L, Radford C, Dart JKG, Edwards $\mathrm{K}$ et al. Risk factors for microbial keratitis in daily disposable contact lens wear. Invest Ophthalmol Vis Sci 2010; 51: e-abstract 1305.

21 Stapleton F, Edwards K, Keay L, Naduvilath T, Dart J, Brian G et al. Severe keratitis in daily contact lens use. Invest Ophthalmol Vis Sci 2008; 49: e-abstract 4853.

22 Willcox M, Carnt N, Diec J, Naduvilath T, Evans V, Stapleton $\mathrm{F}$ et al. Contact lens case contamination during daily wear of silicone hydrogels. Optom Vis Sci 2010; 87: 456-464.

23 Wilson LA, Schlitzer RL, Ahearn DG. Pseudomonas corneal ulcers associated with soft contact-lens wear. Am J Ophthalmol 1981; 92: 546-554.

24 Mondino BJ, Weissman BA, Farb DM, Pettit TH. Corneal ulcers associated with daily-wear and extended-wear and extended-wear contact lenses. Am J Ophthalmol 1986; 102: 58-65.

25 Mayo MS, Schlitzer RL, Ward MA, Wilson LA, Ahearn DG. Association of pseudomonas and serratia corneal ulcers with use of contaminated solutions. J Clin Microbiol 1987; 25: 1398-1400.

26 Stapleton F, Dart JKG, Seal DV, Matheson M. Epidemiology of Pseudomonas aeruginosa keratitis in contact lens wearers. Epidemiol Infect 1995; 114: 395-402.

27 Wiley L, McAllister M, Wiley LA, Elliot T, Bridge D, Odom $\mathrm{J}$. Bacterial biofilm diversity: association with disease severity in contact lens related keratitis. Invest Ophthalmol Vis Sci 2011; 52: e-abstract 6508.

28 Bennett HG, Hay J, Devonshire P, Seal DV, Kirkness CM. Antimicrobial treatment of presumed microbial keratitis: guidelines for treatment of central and periopheral ulcers. Br J Ophthalmol 1998; 137-145.

29 Liesegang TJ, Forster RK. Spectrum of microbial keratitis in South Florida. Am J Ophthalmol 1980; 90: 38-47.

30 Houang E, Lam D, Fan D, Seal D. Microbial keratitis in Hong Kong: relationship to climate, environment and contact lens disinfection. Transact $R$ Soc Trop Med Hyg 2001; 95: 361-367.

31 Gopinathan U, Sharma S, Garg P, Rao GN. Review of epidemiological features, microbiological diagnosis and treatment outcome of microbial keratitis. Ind J Ophthalmol 2009; 57: 273-279.

32 Galentine PG, Cohen EJ, Laibson PR, Adams CP, Michaud R, Arentsen JJ. Corneal ulcers associated with contact lens wear. Arch Ophthalmol 1984; 102: 891-894.

33 Alfonso E, Mandelbaum S, Fox MJ, Forster RK. Ulcerative keratitis associated with contact lens wear. Am J Ophthalmol 1986; 101: 429-433.

34 Schein OD, Ormerod LD, Barraquer E, Alfonso E, Egan KM, Paton BG et al. Microbiology of contact lens-related keratitis. Cornea 1989; 8: 281-285.

35 Wang A-G, Wu C-C, Liu J-H. Bacterial corneal ulcer: a multivariate study. Ophthalmologica 1998; 212: 126-132. 
36 Stapleton F, Keay LJ, Sanfilippo PG, Katiyar S, Edwards KP Naduvilath T. Relationship between climate, disease severity, and causative organism for contact lens associated microbial keratitis in Australia. Am J Ophthalmol 2007; 144: 690-698.

37 Radford C, Lehmann O, Dart J. Acanthamoeba keratitis: multicentre survey in England 1992-1996. Br J Ophthalmol 1998; 82: 1387-1392.

38 Willcox M. Pseudomonas aeruginosa infection and inflammation during contact lens wear: a review. Optom Vis Sci 2007; 84: 273-278.

39 Szczotka-Flynn LB, Pearlman E, Ghannoum M. Microbial contamination of contact lenses, lens care solutions and their accessories. Eye Contact Lens 2010; 2: 116-129.

40 McLaughlin-Borlace L, Stapleton F, Matheson M, Dart JKG Bacterial biofilm on contact lenses and lens storage cases in wearers with microbial keratitis. J Appl Microbiol 1998; 84: 827-838.

41 Szczotka-Flynn LB, Imamura Y, Chandra J, Yu C, Mukherjee PK, Pearlman E et al. Increased resistance of contact lens-related bacterial biofilms to antimicrobial activity of soft contact lens care solutions. Cornea 2009; 28: 918-926.

42 Lakkis C, Fleiszig SMJ. Resistance of Pseudomonas aeruginosa isolates to hydrogel contact lens disinfection correlates with cytotoxic activity. J Clin Microbiol 2001; 39: 1477-1486.

43 Cavanagh HD, Ladage PM, Li SL, Yamamoto K, Molai M, Ren DH. Effects of daily and overnight wear of a novel hyper oxygen-transmissible soft contact lens on bacterial binding and corneal epithelium: a 13-month clinical trial. Ophthalmol 2002; 109: 1957-1969.

44 Fleiszig SM, Evans DJ, Do N, Vallas V, Shin S, Mostov KE. Epithelial cell polarity affects susceptibility to Pseudomonas aeruginosa invasion and cytotoxicity. Infect Immun 1997; 65: 2861-2867.

45 Robertson DM, Petroll WM, Jester JV, Cavanagh HD. Current concepts: contact lens related pseudomonas keratitis. Contact Lens Ant Eye 2007; 30: 94-107.

46 Paugh J, Stapleton F, Keay L, Ho A. Tear exchange under hydrogel lenses. Invest Ophthalmol Visual Sci 2001; 42: 2813-2820.

47 Barbieri JT, Sun J. Pseudomonas aeruginosa ExoS and ExoT. Rev Physiol Biochem Pharmacol 2004; 152: 79-92.

48 Sato H, Frank DW. ExoU is a potent intracellular phospholipase. Mol Microbiol 2004; 53: 1279-1290.

49 Feltman H, Schulert G, Khan S, Jain M, Peterson L, Hauser AR. Prevalence of type III secretion genes in clinical and environmental isolates of Pseudomonas aeruginosa. Microbiology 2001; 147: 2659-2669.

50 Choy MH, Stapleton F, Willcox MDP, Zhu H. Comparison of virulence factors in Pseudomonas aeruginosa strains isolated from contact lens- and non-contact lens-related keratitis. J Med Microbiol 2008; 57: 1539-1546.

51 Janeway CAJ, Medzhitov R. Innate immune recognition. Ann Rev Immunol 2002; 20: 197-216.

52 Veesenmeyer JL, Hauser AR, Lisboa T, Rello J. Pseudomonas aeruginosa virulence and therapy: evolving translational strategies. Crit Care Med 2009; 37: 1777-1786.

53 Khor WB, Aung T, Saw SM, Wong TY, Tambyah PA, Tan AL et al. An outbreak of Fusarium keratitis associated with contact lens wear. JAMA 2006; 295: 2867-2873.

54 Alfonso E, Miller D, Cantu-diboildox J, O'Brien TP, Schein OD. Fungal keratitis associated with non-therapeutic soft contact lenses. Am J Ophthalmol 2006; 142: 154-155.
55 Chang DC, Grant GB, O'Donnell K, Wannemuehler KA, Noble-Wang J, Rao CY et al. Multistate outbreak of Fusarium keratitis associated with use of a contact lens solution. JAMA 2006; 296: 953-963.

56 Saw SM, Ooi P-L, Tan DTH, Khor WB, Fong CW, Lim J et al. Risk factors for contact lens-related Fusarium keratitis. Arch Ophthalmol 2007; 125: 611-617.

57 Bullock JD, Warwar RE, Elder BL, Northern WI. Temperature instability of $\mathrm{ReNu}$ with MoistureLoc: a new theory to explain the worldwide Fusarium keratitis epidemic of 2004-2006. Arch Ophthalmol 2008; 126: 1493-1498.

58 Levy B, Heiler D, Norton S. Report on testing from an investigation of Fusarium keratitis in contact lens wearers. Eye Contact Lens 2006; 32: 256-261.

59 Kilvington S, Powell CH, Lam A, Lonnen J. Antimicrobial efficacy of multi-purpose contact lens disinfectant solutions following evaporation. Contact Lens Ant Eye 2011; 34: 183-187.

60 Gower EW, Keay LJ, Oechsler RA, Iovieno A, Alfonso EC, Jones DB et al. Trends in fungal keratitis in the United States, 2001 to 2007. Ophthalmology 2010; 117: 2263-2267.

61 Joslin CE, Tu EY, McMahon TT, Passaro DJ, Stayner LT, Sugar J. Epidemiological characteristics of a Chicago-area Acanthamoeba keratitis outbreak. Am J Ophthalmol 2006; 142: 212-217.

62 Thebpatiphat N, Hammersmith KM, Rocha FN, Rapuano CJ, Ayres BD, Laibson PR et al. Acanthamoeba keratitis - a parasite on the rise. Cornea 2007; 26: 701-706.

63 Por YM, Mehta JS, Chua JLL, Koh TH, Khor WB, Fong AC et al. Acanthamoeba keratitis associated with contact lens wear in Singapore. Am J Ophthalmol 2009; 148: 7-12.e2.

64 Joslin CE, Tu EY, Shoff ME, Booton GC, Fuerst PA, McMahon TT et al. The association of contact lens solution use and Acanthamoeba keratitis. Am J Ophthalmol 2007; 144: 169-180.

65 Verani JR, Lorick SA, Yoder JS, Beach MJ, Braden CR, Roberts JM et al. National outbreak of Acanthamoeba keratitis associated with use of a contact lens solution, United States. Emerg Infect Dis 2009; 15: 1236-1242.

66 Tu EY, Joslin CE. Recent outbreaks of atypical contact lensrelated keratitis: what have we learned? Am J Ophthalmol 2010; 150: 602-608.e2.

67 Smith AJ, Humphries SE. Cytokine and cytokine receptor gene polymorphisms and their functionality. Cytokine Growth Factor Rev 2009; 20: 43-59.

68 Hazlett LD, McClellan S, Kwon B, Barrett R. Increased severity of Pseudomonas aeruginosa corneal infection in strains of mice designated as Th1 vs Th2 responsive. Invest Ophthalmol Visual Sci 2000; 41: 805-810.

69 Keijser S, Kurreeman FA, de Keizer RJ, Dogterom-Ballering H, van der Lelij A, Jager MJ et al. IL-10 promotor haplotypes associated with susceptibility to and severity of bacterial corneal ulcers. Exp Eye Res 2009; 88: 1124-1128.

70 Carnt N, Willcox M, Hau S et al. Association of single nucleotide polymorphisms of Interleukin 1 Beta and Interleukin 6 and susceptibility and severity of keratitis amongst contact lens wearers. Optom Vis Sci 2011 e-abstract.

71 Fishman D, Faulds G, Jeffery R, Mohamed-Ali V, Yudkin JS, Humphries $\mathrm{S}$ et al. The effect of novel polymorphisms in the interleukin-6 (IL-6) gene on IL-6 transcription and plasma IL-6 levels, and an association with systemic-onset juvenile chronic arthritis. J Clin Invest 1998; 102: 1369-1376.

72 Cole N, Bao S, Willcox M, Husband AJ. Expression of interleukin-6 in the cornea in response to infection with 
different strains of Pseudomonas aeruginosa. Infect Immun 1999; 67: 2497-2502.

73 Hume EB, Cole N, Garthwaite LL, Khan S, Willcox MD. A protective role for IL-6 in staphylococcal microbial keratitis. Invest Ophthalmol Visual Sci 2006; 47: 4926-4930.

74 Seal DV, Kirkness CM, Bennett HGB, Peterson M. Populationbased cohort study of microbial keratitis in Scotland: incidence and features. Contact Lens Ant Eye 1999; 22: 49-57.

75 Morgan PB, Efron N, Raynor MK, Whiting MA, Tullo AB. Incidence of keratitis of varying severity among contact lens wearers. Br J Ophthalmol 2005; 89: 430-436.
76 Nilsson SE, Montan PG. The annualized incidence of contact lens induced keratitis in Sweden and its relation to lens type and wear schedule: results of a 3-month prospective study. CLAO J 1994; 20: 225-230.

77 Schein OD, McNally JJ, Katz J, Chalmers RL, Tielsch JM, Alfonso $\mathrm{E}$ et al. The incidence of microbial keratitis among wearers of a 30 day silicone extended wear contact lens. Ophthalmology 2005; 112: 2172-2179.

78 Stapleton F, Keay L, Jalbert I, Cole N. The epidemiology of contact lens related corneal infiltrates. Ophthalmol Vis Sci 2007; 84: 257-272. 